\title{
Cadbury India - Sweet Turning Sour
}

\author{
Semila F Fernandes*, Pooja Gupta ${ }^{\dagger}$ and A Vidyasagar**
}

Mondelez global CEO Irene Rosenfeld has been concerned over slow growth in India unit. Since 2015, she has expressed her concern over this slow growth rate. "India is a market that we're watching closely....... It's just growing at a slower rate than it had been. So I want to be very clear; it's just we'd like to see it get back up to the high single-digit, double-digit rates that it had been growing at since we acquired the Cadbury business." 1 Rosenfeld had said at an investors call in August last year. ${ }^{2}$

Mondelez India, which acquired Cadbury India in 2012, was seeking to boost growth, which had fallen to single digits in the first half of 2015.

By playing in the meeth $a^{3}$ space, and directly competing with traditional Indian sweets, Cadbury had set itself up for a tough slog. "When you say thanda matlab ${ }^{5}$ Coca-Cola ${ }^{6}$ you are competing

* Symbiosis Institute of Business Management, Bengaluru (SIBM), Constituent of Symbiosis International University, Bengaluru, India; semila.fernandes@sibm.edu.in

+ SIBM, Constituent of Symbiosis International University, Bengaluru, India; poojagupta@sibm.edu.in

** SIBM, Bengaluru, Constituent of Symbiosis International University, Bengaluru, India;

${ }^{1}$ http:/ / articles.economictimes.indiatimes.com/2015-08-

06/news/65280961_1_mondelez-india-cadbury-india-chocolate-category

${ }^{2} \mathrm{Feb} 2016$ :

http:/ / brandequity.economictimes.indiatimes.com/news/business-ofbrands/cadbury-maker-mondelez-posts-slowest-growth-in-over-10years $/ 50970580$

${ }^{3}$ Meetha in Hindi means sweet

4Thanda in Hindi means Cold 
with seven brands of soft drink. But when you say kuch meetha ho jaaye $^{7}$ you are competing with thousands of traditional sweets including regional favourites. It's a good piece of strategy, but whether it's effective is the question," 8 is the opinion of marketing consultant Harish Bijoor. He further feels that apart from the social sanctions against adults eating chocolates which are still in place, there's the functional idea of chocolates being a sugar rich category and therefore not good for health which is becoming a hindrance for growth of Cadbury.

\section{Chocolate Industry in India: ${ }^{9}$}

Traditionally, the chocolate industry was segmented based on the type of the ingredients used in its production which includes milk, dark and white chocolates (See Exhibit1). The industry growth was driven by the increase in disposable income, increasing trend in gifting chocolates and changing lifestyle. As per Euromonitor International report in 2014, growth in chocolate market in India had been much higher in India when compared to the other BRICS ${ }^{10}$ countries especially during 2006-2013. (See Exhibit 2). As per the same report, it had been seen that over 2009-2014, the rural consumption has expanded more than the urban consumption.

Exhibit 2 also highlights the fact that from 2008 till 2012, Indian chocolate industry had grown at an average of $13.5 \%$ per annum. In 2013-14 the chocolate industry in India had been estimated at INR 58 billion which showed a Compounded Annual Growth rate of $15 \%$ over the last three years. It can also be seen that the market share of 'Others' category has increased significantly from 2009 to 2014 and the established players in the Indian market Nestle and

${ }^{5}$ Matlab in Hindi means meaning

${ }^{6}$ This refers to an iconic advertisement of Coca Cola India in 2006 where the ad referred generic cold drink as Coca Cola

${ }^{7}$ The tag line means lets have some sweets. Cadbury had come up with this in tagline in 2010

8http://in.mondelezinternational.com/newsroom/ /media/010E0AB30 E1A4F8D8E7C67BB47B99871.ashx

9http://www.indianmirror.com/indian-industries/2015/chocolate-

2015.html

${ }^{10}$ BRICS- Brazil, Russia, India, China and South America. Acronym for emerging economies 
Gujarat Cooperative (Amul Brand) have lost their market share. The only company which had been able to improve on its market share is Cadbury India which has been renamed Mondelez India. (See Exhibit 3 for Cadbury India's sales growth and Exhibit 4 for different companies and their brands of Chocolates available in India).

\section{Cadbury's Journey in India ${ }^{11}$}

Cadbury has had a long and successful journey in India. In 1946 Cadbury started its first production operation in Mumbai ${ }^{12}$ which was later shifted to Thane ${ }^{13}$. Cadbury India Private Limited was established in 1948 in India as a subsidiary of Cadbury Plc. Based in United Kingdom.

In 1964, Cadbury India chose to setup a new plant near Pune ${ }^{14}$ to stimulate new methods in chocolate production as well as to be able to improve and expand the milk yield. The company delved in cocoa farming in India to diminish dependence on imported cocoa beans. In 1981-82, a fresh chocolate manufacturing unit was set up in the same area. In 1989, the company set up a plant at Malanpur ${ }^{15}$, Madhya Pradesh ${ }^{16}$, which was in a remote area to reap the benefits of setting up manufacturing units ${ }^{17}$ in the backward areas. Since 1995, Cadbury's dependence on Malanpur plant had increased. The Malanpur plant has updated amenities for various product categories such as Gems, Eclairs etc. The company has launched new products periodically to expand its product portfolio. (See Exhibit 5 for Company's timeline)

\footnotetext{
${ }^{11}$ www.indianmirror.com/indian-industries/chocalate.html

12 Capital City of Indian state of Maharashtra

13 Suburban area of Mumbai City

${ }^{14}$ Industrial city in the state of Maharashtra

15 Small town in Central Indian state of Madhya Pradesh

16 State in Central India

17 Government Policy in 1989 gave extra tax benefits to manufacturing units set up in remote areas
} 


\section{From Cadbury India to Mondelez India Foods Private Limited ${ }^{18}$}

In January 2010, Kraft Foods, a US based food and confectionery giant took over Cadbury Plc. in a hostile takeover for around 11.9 billion pound sterling. This had an effect on the ownership of Cadbury India as it then became a subsidiary of Kraft Foods. Within 2 years of the takeover, Cadbury was moved from Kraft Foods to Mondelez under a reorganisation of Kraft Foods. In October 2012 Cadbury India Ltd, was renamed as Mondelez India Foods Ltd. The change in ownership has not affected the brand much in India as the brand name and original packaging has been retained.

As per a report by Societe Generale ${ }^{19}$ in 2015 , it is mentioned that in the next five years, global confectioners will see the highest growth in four markets: India, Brazil, Mexico and China20. Exhibit 6 highlights the dominance of Cadbury Brand in the Indian chocolate market. Out of the top ten chocolate brands in India based on value share, five of the brands belong to Mondelez India with Cadbury Dairy Milk leading from the front with a 30.4\% share. Cadbury Dairy milk has been the flagship brand of the company from the time it was launched in 1984. Cadbury India over the time period has promoted Cadbury Dairy Milk as more than a sweet or a chocolate.

\section{Cadbury Dairy Milk: Harbinger of Emotions}

Over the last two decades, Cadbury Dairy Milk has been able to build an integral relationship with the Indian consumer. The communication and customer connect strategy of Cadbury in India with respect to its Cadbury Daily Milk brand has made it an integral part of life for its consumers. The chocolate has risen above just being a brand and has become a constant companion for the consumer on her emotional journey of life. Whether it is the expression of achievement or joy, times of sheer sadness, periods of nervousness, fits of anger, and bursts of laughter or sharing the

\footnotetext{
${ }^{18} \mathrm{http}: / /$ articles.economictimes.indiatimes.com/2014-06-24/ news/ 5082

5997_1_cadbury-india-mondelez-international-mondelez-india ${ }^{19}$ French Investment Bank

${ }^{20 h t t p: / / q z . c o m / 445298 / t h e-d e l i c i o u s-t r u t h-i n d i a-i s-o n e-o f-t h e-f a s t e s t-~}$ growing-chocolate-markets-in-the-world/
} 
perfect love stricken moment; Cadbury Dairy Milk has been a part of all of it.

\section{Cadbury Dairy Milk's Slice of Life Communication Message}

Cadbury Dairy Milk has been able to build this unique connect with the consumer through its one of a kind promotion and advertising strategy. The promotion strategy followed by the company is somewhat unique- instead of focusing on the product, it seeks to tap into emotions normally associated with chocolates. The ads of Cadbury Dairy Milk have been a testimony to the brand's ability to position and reposition its products time and again, in order to capture and retain its market share.

Pre 1990's, Cadbury Dairy Milk ads were focused on children alone and talked more about the product. In Mid 1990's the focus of the promotional messages changes and started focussing more on adults and positioned chocolate consumption as a sign of love and friendship. Since then the company has built on this promotion message and have continuously portrayed Cadbury Dairy Milk as something to be had for celebration. They have promoted having the Cadbury Dairy Milk chocolate as a celebration of win in sports, in exams and other fields. The company has also portrayed the chocolate being an alternative gift item or something to be had in place of traditional sweets. (See Exhibit 7 and 8 for details of the advertisements of Cadbury Dairy Milk over the years)

This particular strategy of Cadbury has proven to be very successful. Cadbury Dairy milk has been positioned more as a lifestyle choice and a treat to be had at different good points in life.

\section{Cadbury Dairy Milk - Sweet Dream Turning Sour ${ }^{21}$}

The year 2015 was not good for the chocolate industry in India as the sales fell by $2 \%$ in the first half of the year. This sounded a major alarm for Mondelez India. Although, Mondelez India has lot of products in its portfolio, it was majorly dependent on chocolate category for its revenues and profits.

${ }^{21}$ http:/ / articles.economictimes.indiatimes.com/2015-08-19/news/6559

2521 _1_chocolates-price-increases-cadbury-dairy-milk 
In early 2015, Cadbury sales saw a drop which has been the highest slump since 2005 which the company has attributed to the increase in commodity prices, depreciation in rupee and economic slowdown. The company as a result has started investing heavily in sales and market expansion in India with the prime focus being rural India. 22

Manu Anand, CEO of Mondelez took helm of the company when it was taken over. This current slump in the market is one of the first big challenge in front of Anand. According to several industry experts, Anand has to deal with several major areas of churn like transforming an old organization with a majority new team at the top management along with old members. The second challenge is the product front where their primary product chocolate is struggling with high input costs and growing competition. Prashant Peres, director, marketing (chocolates) at Mondelez India ${ }^{23}$, has pointed out that the company has introduced innovative products in the premium chocolate category and expanded the Cadbury Daily Milk Brand in the premium category as 'Silk'.

In order to protect the market leader's position of Cadbury Dairy Milk in the chocolate market, the big question is whether the same promotional strategy will work in the future for Cadbury Dairy Milk or not.

\section{Type of ingredient in Chocolate (popularity in \%)}

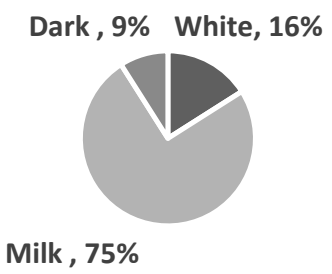

$22 \mathrm{http}$ // articles.economictimes.indiatimes.com/2014-02-20/news/ 47527437_1_cadbury-india-mondelez-international-heinz-india ${ }^{23} \mathrm{http}$ :/ / qz.com/445298/the-delicious-truth-india-is-one-of-the-fastestgrowing-chocolate-markets-in-the-world/ 


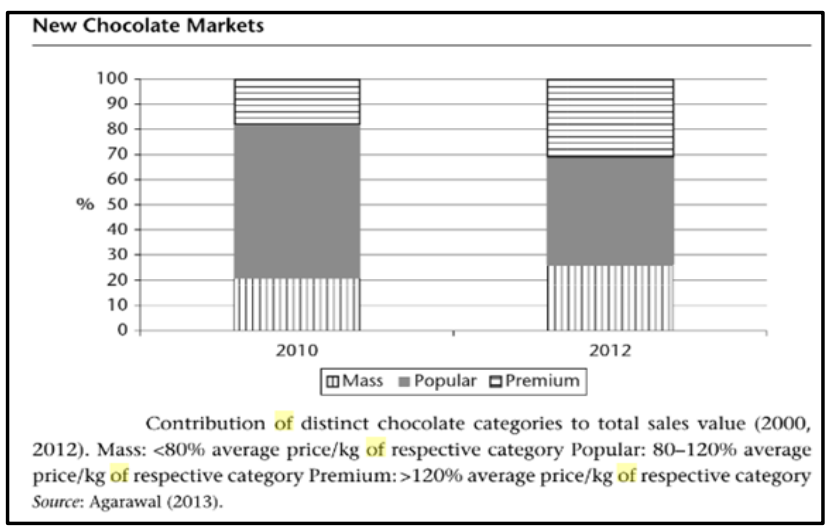

Exhibit 1: Type of Ingredient in Chocolate

Source: http://www.valuenotes.biz/insights-publications/publications/chocolate-industry-in-india2014-19/
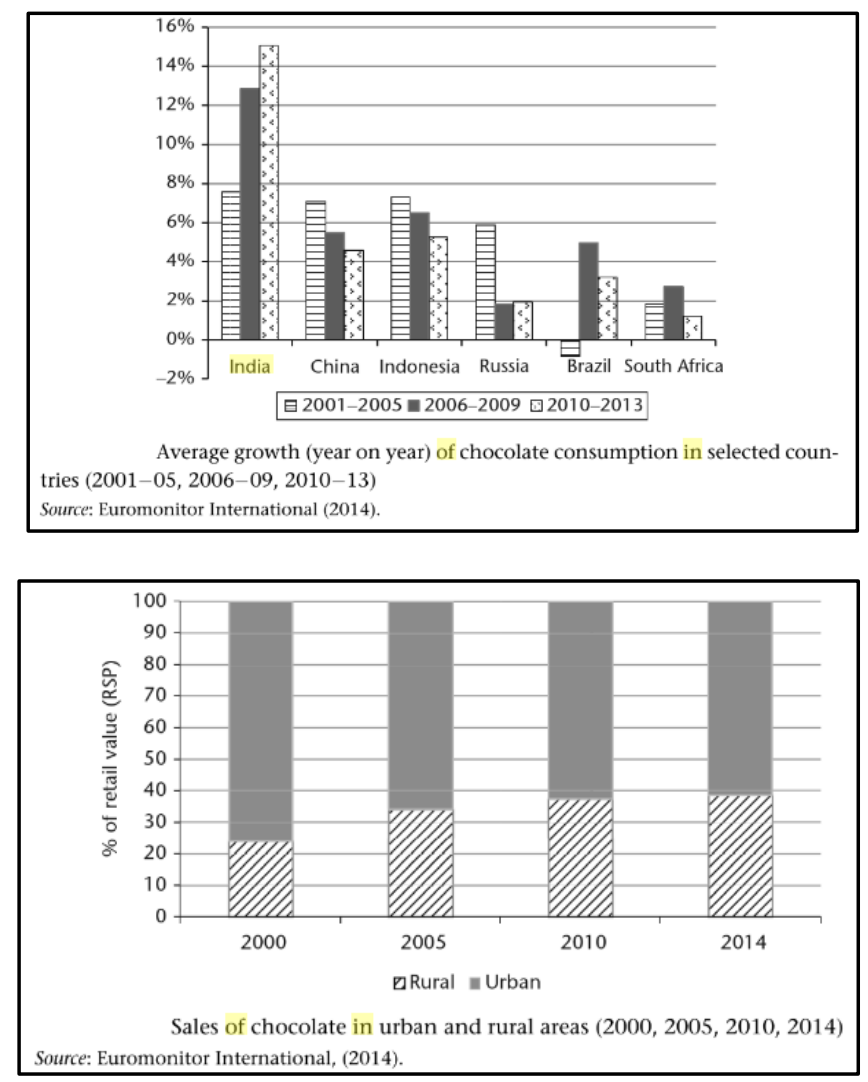


\begin{tabular}{|lcc|}
\hline \multicolumn{2}{|c|}{ Company shares of chocolate confectionery (\% of retail value) } \\
\hline Companies & 2009 & 2013 \\
\hline Cadbury India & 57.9 & - \\
Mondelēz International & - & 56.3 \\
Nestlé India & 30.1 & 21.3 \\
Ferrero India & 3.7 & 4.7 \\
Gujarat Cooperative & 3.2 & 1.2 \\
Mars Confectionery & - & 1.1 \\
Lindt & 0.1 & 0.2 \\
Others & 4.9 & 15.1 \\
\hline Source: Euromonitor International (2014). & & \\
\hline
\end{tabular}

Exhibit 2: Economic Data of Chocolate Industry

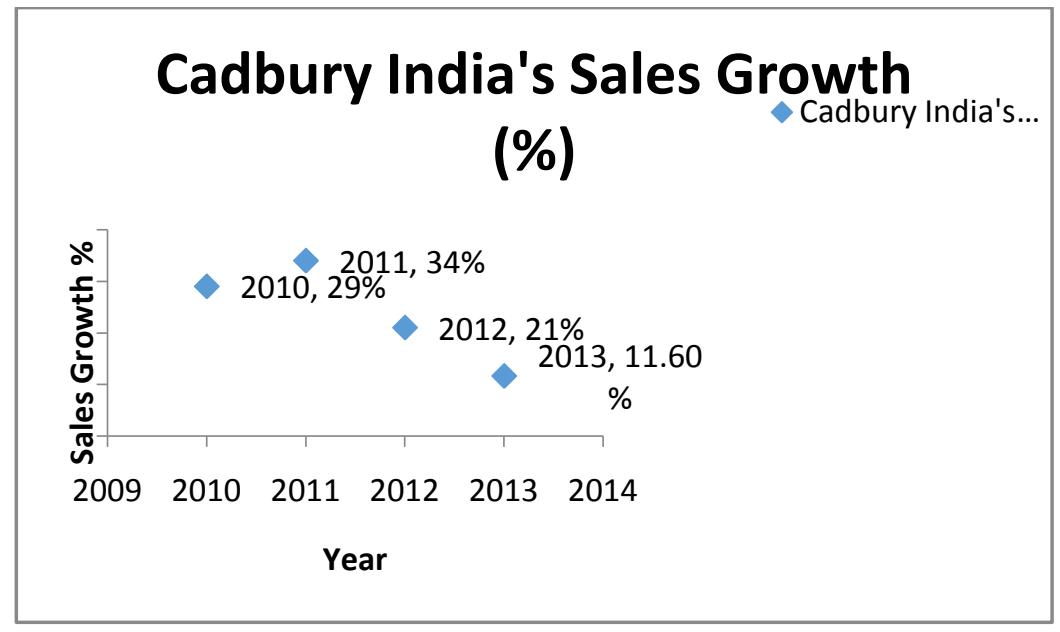

Exhibit 3:Cadbury India's Sales Growth

Source: http://articles.economictimes.indiatimes.com/2014-02-20/news/47527437_1_cadbury-indiamondelez-international-heinz-india

\begin{tabular}{|l|l|}
\hline Company & Brands \\
\hline Cadbury & Dairy Milk \\
& 5 Star \\
& Gems \\
& Perk \\
& Silk \\
& Bournville \\
\hline
\end{tabular}




\begin{tabular}{|l|l|}
\hline & Celebrations \\
\hline Nestle & Extra Smooth \\
& Kit Kat Senses \\
& Kit Kat Dark Senses \\
& Alpino \\
& Kit Kat \\
& Bar-One \\
& Munch \\
\hline Ferrero India & Ferrero Rocher \\
& Nutella \\
& Kinder \\
& Raffaello \\
& Mon Cheri \\
\hline Amul & Milk Chocolate \\
& Dark Chocolate \\
& Fruit \& Nut Chocolate \\
& Tropical Orange Chocolate \\
& Almond Bar \\
\hline Mars & Snickers \\
International & Galaxy \\
& Mars \\
& Milky Way \\
& M\&M's \\
& Twix \\
\hline
\end{tabular}

Exhibit 4:India's Major and Popular Chocolate Brands 24

Source-compilation by the case authors

1948 - Incorporated on 19th July, as Cadbury-Fry (India) Private Limited

1964 - Development of cocoa growing in the country

1967 - Introduced the 'Five Star and Gems' chocolates in 1967 and 1968 respectively.

1977 - Cadbury-Fry (India) Pvt. Ltd., was changed to Cadbury India Pvt. Ltd., on 7th June and was converted into public limited company on 11th June.

1978 - Proposed to acquire process knowledge and technology from Cadbury Schweppes plc. (CSP)

24 http:/ / business.mapsofindia.com/top-brands-india/top-chocolatebrands-in-india.html 
1981 - Received a certificate to manufacture 2,200 tonnes of chocolates at Indori.

1982 - 17th December, Cadbury India Ltd. Was changed to Hindustan Cocoa Products Ltd.,

1984 - Dairy Milk Chocolate was launched

1985 - Explored the possibilities of entering into software export

1986 - Received approval of the Company Law Board for software business

1987 - Under chocolate segment, launched new products such as 'Crackle', 'Orange', 'Strawberry Krisp', 'Mello', and 'Wildlife bar'.

1988 - Company diversified into ice-cream market and a product under the Brand name 'Dollops' was test marketed in Hyderabad on New year's day. To meet the demand for the food drink category, a new factory at Malanpur was established.

1989 - Food drinks product was marketed under 'Enriche' brand name. Effective 1st December, the name of the Company was changed from Hindustan Cocoa Products, Ltd. to Cadbury India, Ltd.

1993 - From 18th July, The Ice Cream business engagement with two well known brands Dollops \& Lopstop was transferred to Brooke Bond India Ltd.

1994 - At the Malanpur factory, modernization and rationalisation Programme was conducted

1995 - At Malanpur plant, 'Perk' was launched. Towards the end of 1996, new range of sugar confectionery, 'Googly' was launched.

1997 - Launched Truffle, Bournvita sachets

1998 - Launches Picnic and celebrating golden jubilee in India.

1999 - Launches 'Nice Crem', under sugar confectionery business. Its new wafer product, Perk, was launched in Sep.'95.

2000 - Introduces Perk Slims and four new layers covered in Cadbury Dairy Milk Chocolate along with a range of gift packs for Diwali.

2001 - Mathew Cadbury took over as the new Managing Director of Cadbury India Ltd. from February 5. 
2002 - Cadbury Schweppes Plc acquires 39.34\% stake in its Indian subsidiary Cadbury India Ltd. Cadbury's market share slipped $70.7 \%$ due to competition.

2003 - Lauches Cadbury's Heroes and re-launches its flagship brand 'Cadbury Dairy Milk'.

2004 - Amitabh Bachchan became the new brand ambassdor for Cadbury Dairy Milk

2005 - Cadbury Schweppes Asia-Pacific announced Mr Bharat Puri as the Managing Director of Indian sub-continent

2007 - Rolled out a wafer-based chocolate called 'Ulta Perk' 25

2010 - In January 2010 Kraft Foods acquired Cadbury globally in a hostile takeover

2012 - Cadbury and non-grocery businesses of Kraft were combined to form Mondelez listed on NY stock exchange ${ }^{26}$

Exhibit 5: Company History Timeline

\begin{tabular}{|l|r|}
\hline Top 10 Chocolate Brands & Value Share (\%) \\
\hline Cadbury Dairy Milk (Mondelez India) & 30.4 \\
\hline 5 Star (Mondelez India) & 7.9 \\
\hline Munch (Nestle India & 6.7 \\
\hline Kit Kat (Nestle India & 5.4 \\
\hline Cadbury Gems (Mondelez India) & 5.4 \\
\hline Cadbury Perk (Mondelez India) & 4.2 \\
Cadbury Celebrations (Mondelez India) & 3.1 \\
\hline Kinder Joy (Ferrero India) & 3 \\
\hline Nestle Premium Milk Chocolate (Nestle Indi & 2.4 \\
\hline Ferrero Rocher (Ferrero India) & 2 \\
\hline
\end{tabular}

${ }^{25} \mathrm{http}: / /$ www.moneycontrol.com/company-facts/cadburyindia/ history/ CI

26http:/ / articles.economictimes.indiatimes.com/2014-06-

24/news/50825997_1_cadbury-india-mondelez-international-

mondelez-india 


\begin{tabular}{|l|c|c|c|c|}
\hline \multicolumn{5}{|c|}{ Pecking Order } \\
\hline $\begin{array}{l}\text { Mondelez India dominated the order followed by Nestle. However, } \\
\text { share of almost all established companies slipped. }\end{array}$ \\
\hline Mondelez India (Cadbury) & Nestle & Ferrero & \multicolumn{2}{c|}{ GCMMF Others } \\
\hline 55.5 & 17 & 5 & 1.1 & 21.4 \\
\hline $\begin{array}{l}\text { \% of retail value in 2014 A } \\
\text { Sweet Growth }\end{array}$ & & & & \\
\hline $\begin{array}{l}\text { Sales Show in Chocolate } \\
\text { Market Volume ('000 tonnes), } \\
\text { Value (Rs. '000 cr) }\end{array}$ & & & & \\
\hline
\end{tabular}
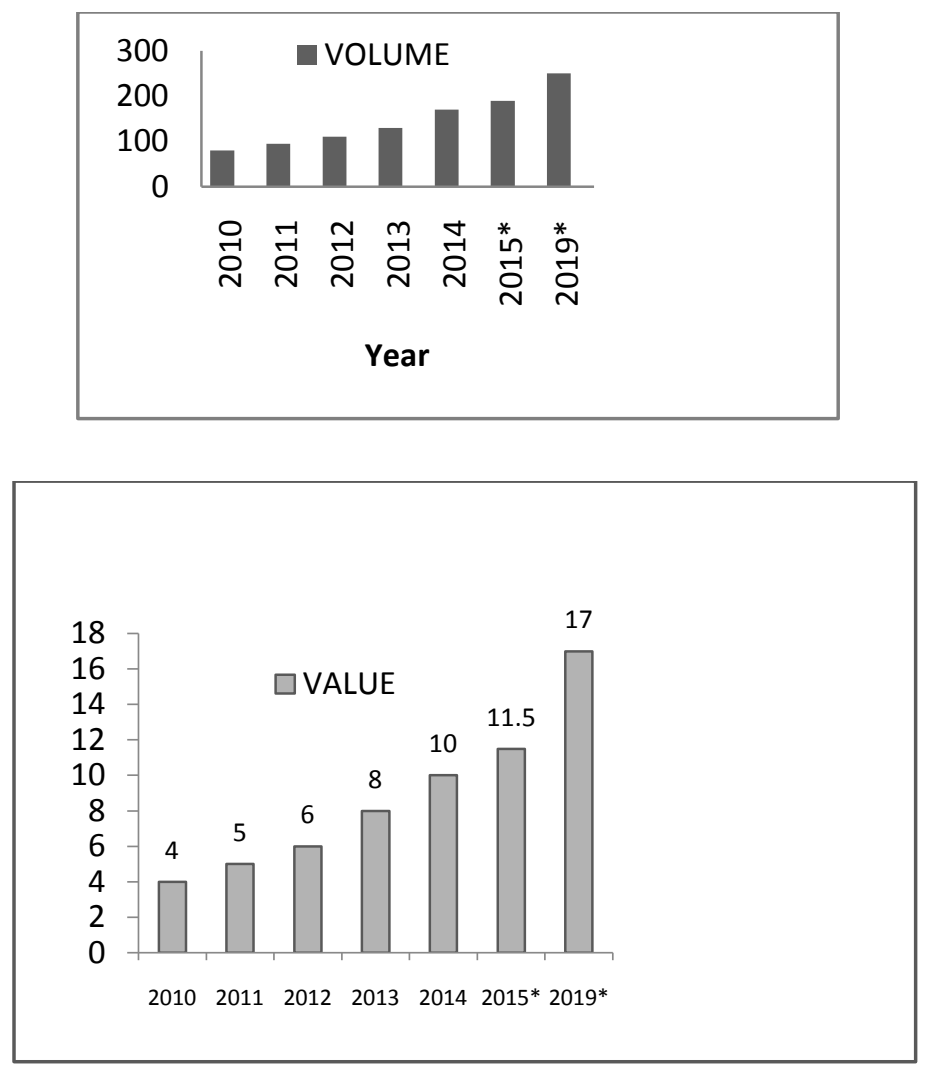

Exhibit 6: Chocolate Segment in India 2014

Source: http://articles.economictimes.indiatimes.com/2015-02-16/news/59196990_1_mondelez-indiacadbury-india-chocolate 


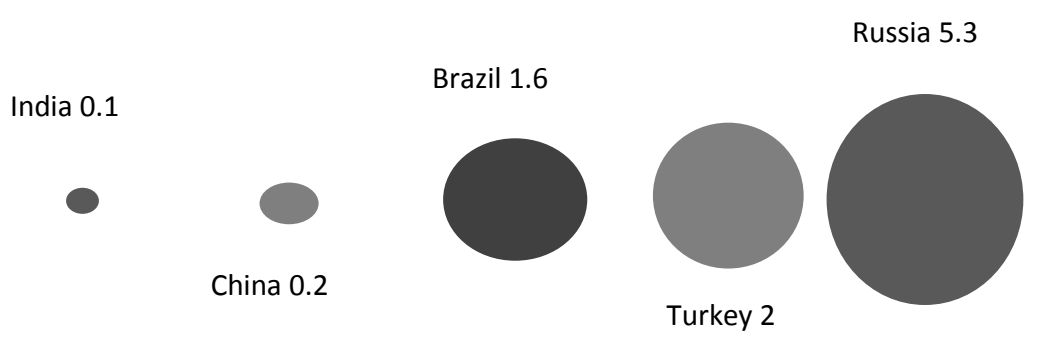

Chocolate sales are likely to grow at $11 \%$ CAGR in value terms at constant 2014 prices over the forecast period. Growth will be driven by lower-priced chocolates in rural areas and increased uptake of premium ones in urban India. According to Euromonitor report

Exhibit7:IN 1955, TV ADVERTISEMENTS BEGAN ITS JOURNEY FOR CADBURY

\begin{tabular}{|l|l|l|l|l|}
\hline Pre 1990's & Mid 90's & late '90's & Mid ‘00s & Post 2000's \\
\hline $\begin{array}{l}1955 \text { - Cadbury } \\
\text { drinking chocolate }\end{array}$ & $\begin{array}{l}\text { Real taste } \\
\text { of life }\end{array}$ & $\begin{array}{l}\text { Khane } \\
\text { walo ko } \\
\text { bahana } \\
\text { chahiye }\end{array}$ & $\begin{array}{l}\text { 2005 - } \\
\text { Pappu } \\
\text { Pass Ho } \\
\text { Gaya }\end{array}$ & $\begin{array}{l}\text { 2004- 2005 - } \\
\text { Cadbury } \\
\text { Bytes - only } \\
\text { sweet snack }\end{array}$ \\
\hline $\begin{array}{l}\text { 1957 - 13 one } \\
\text { minute films } \\
\text { describing } \\
\text { harvesting of an } \\
\text { ingredient used at } \\
\text { Cadbury }\end{array}$ & & $\begin{array}{l}\text { Kuch } \\
\text { Meetha } \\
\text { Ho Jaaye }\end{array}$ & $\begin{array}{l}\text { Miss } \\
\text { Palampur }\end{array}$ & $\begin{array}{l}\text { 2007 } \\
\text { Gorilla } \\
\text { premiers }\end{array}$ \\
\hline $\begin{array}{l}1968 \text { - First Milk } \\
\text { Tray Man ad }\end{array}$ & & & & \\
\hline $\begin{array}{l}1970-\text { Campaigns } \\
\text { for flake, Cadbury } \\
\text { Dairy Milk, Fruit } \\
\text { \& Nut and Whole } \\
\text { Nut }\end{array}$ & & & $\begin{array}{l}\text { Cadbury } \\
\text { Celebrati } \\
\text { ons }\end{array}$ & $\begin{array}{l}2009 \text { - Aaj } \\
\text { pehli tarikh } \\
\text { hai }\end{array}$ \\
\hline $\begin{array}{l}1971 \text { - Cadbury } \\
\text { Creme Egg }\end{array}$ & & & $\begin{array}{l}2010-\text { Kuch } \\
\text { Meetha Ho } \\
\text { Jaaye }\end{array}$ \\
\hline $\begin{array}{l}\text { 1981 - Wispa } \\
\text { national ad } \\
\text { campaign }\end{array}$ & & & & \\
\hline
\end{tabular}

Source - compilation by case authors 


\begin{tabular}{|c|c|c|c|c|}
\hline$\#$ & Year & Ads with YouTube Links & Campaign & Description \\
\hline 1 & $\begin{array}{l}\text { Mid } \\
90 ' s- \\
1994\end{array}$ & https://www.youtube.com/watch?v=XBnH3285MGI & $\begin{array}{l}\text { Cadbury } \\
\text { Dairy } \\
\text { Milk Real } \\
\text { Taste Of } \\
\text { Life }\end{array}$ & $\begin{array}{l}\text { A Cricket match is going on. The batsman hosts the } \\
\text { winning six. His girlfriend, who's having Cadbury } \\
\text { gets exited \& jumps to the field with excitement and } \\
\text { starts dancing to celebrate the moment. }\end{array}$ \\
\hline 3 & $\begin{array}{l}\text { Mid } \\
90 \text { 's }\end{array}$ & https://www.youtube.com/watch?v=ufoKtuv3Rzw & $\begin{array}{l}\text { Cadbury } \\
\text { Dairy } \\
\text { Milk Real } \\
\text { Taste Of } \\
\text { Life }\end{array}$ & $\begin{array}{l}\text { This Ad depicts that Cadbury dairy milk is so tatsy } \\
\text { that inspite of having Mehandi applied in her hand } \\
\text { she tries hard to have the chocolate. }\end{array}$ \\
\hline 6 & $\begin{array}{l}\text { Late } \\
90 \text { 's } \\
\text { and } \\
\text { early } \\
\text { 00's }\end{array}$ & https://www.youtube.com/watch?v=NjlGu5l1_IY & $\begin{array}{l}\text { Khanewal } \\
\text { o ko } \\
\text { bahanacha } \\
\text { hiye }\end{array}$ & $\begin{array}{l}\text { A wedding celebration is going on. Instead of sweets } \\
\text { people are celebrating with Dairy Milk. In the back } \\
\text { ground song is playing: "Khanewalon ko Khaneka } \\
\text { bahana Chaie" }\end{array}$ \\
\hline
\end{tabular}




\begin{tabular}{|c|c|c|c|c|}
\hline 7 & $\begin{array}{l}\text { Mid } \\
00 ' s \text { i.e. } \\
2005\end{array}$ & https://www.youtube.com/watch?v=vnfO5hV-89Y & $\begin{array}{l}\text { Pappu } \\
\text { pass ho } \\
\text { gaya }\end{array}$ & $\begin{array}{l}\text { A college setting is shown where a Chocolate shop is } \\
\text { there in the premises. All the students are getting } \\
\text { Dairy Milk from the shop and are not paying for it. } \\
\text { They are saying Pappu will pay for it. When asked } \\
\text { for the reason they say "Pappu Pass Ho Gaya". In the } \\
\text { end pappu turns out to be a middle aged guy } \\
\text { appearing for 12th Standard Exams. }\end{array}$ \\
\hline 8 & $\begin{array}{l}\text { Mid } \\
00 \text { 's }\end{array}$ & https://www.youtube.com/watch?v=nZFnbtmheuE & $\begin{array}{l}\text { Radha } \\
\text { Miss } \\
\text { Palampur }\end{array}$ & $\begin{array}{l}\text { Celebration is going on in a palace where everybody } \\
\text { is saying "Radha was crowned as Miss Palampur". } \\
\text { People are celebrating with Cadbury Dairy Milk }\end{array}$ \\
\hline 9 & 2009 & https://www.youtube.com/watch?v=HoT219u0_Kg & $\begin{array}{l}\text { Cadbury } \\
\text { Dairy } \\
\text { Milk India } \\
\text { TVC - Aaj } \\
\text { Pehli } \\
\text { Tarikh Hai }\end{array}$ & $\begin{array}{l}\text { Young earning girl is depicted getting salary and } \\
\text { going for party and shopping but she also spends } \\
\text { money on buying Cadbury }\end{array}$ \\
\hline
\end{tabular}




\begin{tabular}{|c|c|c|c|c|}
\hline 10 & 2009 & https://www.youtube.com/watch?v=pA_jTzvRKdc & $\begin{array}{l}\text { Cadbury } \\
\text { Dairy } \\
\text { Milk India } \\
\text { TVC - Aaj } \\
\text { Pehli } \\
\text { Tarikh Hai }\end{array}$ & $\begin{array}{l}\text { A vintage setting of a government office is projected } \\
\text { where the employer announces that today is the } \\
\text { salary day. Thus the whole setting changes into a } \\
\text { celebration of getting salary. }\end{array}$ \\
\hline 11 & 2010 & & $\begin{array}{l}\text { Kuch } \\
\text { Meetha } \\
\text { Ho Jaye }\end{array}$ & $\begin{array}{l}\text { There are different settings shown in the Ad. First it's } \\
\text { a rainy day where kids are going to school, as it is a } \\
\text { rainy day the school is off, thus the kids celebrate } \\
\text { with Dairy Milk. Second setting is It's the results day } \\
\text { at a college the student sees his results \& celebrates } \\
\text { with Dairy Milk. And finally a girl takes lift in } \\
\text { Amitabh Bachchan's car \& he offers her a Dairy Milk. }\end{array}$ \\
\hline 12 & 2010 & https://www.youtube.com/watch?v=9MDxGiT_r4g & $\begin{array}{l}\text { Cadbury } \\
\text { Dairy } \\
\text { Milk- } \\
\text { Shubh } \\
\text { Aarambh } \\
\text { "Child's } \\
\text { Play" }\end{array}$ & $\begin{array}{l}\text { Wife is trying to think of ways in which she can tell } \\
\text { her husband about her pregnancy. While she's } \\
\text { thinking of different ways her husband walks in \& } \\
\text { offers a Cadbury Dairy Milk for the celebration of a } \\
\text { new beginning. }\end{array}$ \\
\hline
\end{tabular}




\begin{tabular}{|c|c|c|c|c|}
\hline 13 & 2010 & https://www.youtube.com/watch?v=AvezOXmOkNY & $\begin{array}{l}\text { Cadbury } \\
\text { Dairy } \\
\text { Milk Silk } \\
\text { Traffic } \\
\text { Jam Kiss } \\
\text { me \& miss } \\
\text { me }\end{array}$ & $\begin{array}{l}\text { In a traffic Jam in the middle of town there is a lady } \\
\text { who's having Cadbury Silk without any inhibition of } \\
\text { people observing her. When a guy looks at her from } \\
\text { a nearby car she points out that the guy is also } \\
\text { having Dairy Milk Silk. }\end{array}$ \\
\hline 14 & 2011 & https://www.youtube.com/watch?v=4nnZ1ggLo7Q & $\begin{array}{l}\text { Cadbury } \\
\text { Dairy Milk } \\
\text { in Home - } \\
\text { Lauki : } \\
\text { Meethe } \\
\text { mein kuch } \\
\text { meetha } \\
\text { hojaaye } \\
\end{array}$ & $\begin{array}{l}\text { Husband comes home from work \& asks what's for } \\
\text { Dinner, he gets the answer as "Lauki" (Bottle Gourd). } \\
\text { Seemingly disappointed he asks what is for dessert \& } \\
\text { gets the answer as "Dairy Milk" this pacifies him \& } \\
\text { he becomes happy. }\end{array}$ \\
\hline 15 & 2011 & https://www.youtube.com/watch?v=C44vihlOixk & $\begin{array}{l}\text { Cadbury } \\
\text { Dairy Milk in } \\
\text { Home - } \\
\text { Lauki : } \\
\text { Meethe mein } \\
\text { kuch meetha } \\
\text { ho jaaye }\end{array}$ & $\begin{array}{l}\text { A husband and wife are discussing about dinner and } \\
\text { the mother yells that dinner is again the boring } \\
\text { "Loki" so that they understand that it is obvious that } \\
\text { they have to eat Dairy Milk for desserts }\end{array}$ \\
\hline
\end{tabular}




\begin{tabular}{|c|c|c|c|c|}
\hline 16 & 2011 & https://www.youtube.com/watch?v=rf0X0ycQz3I & $\begin{array}{l}\text { Cadbury } \\
\text { Dairy } \\
\text { Milk in } \\
\text { Home - } \\
\text { Lauki : } \\
\text { Meethe } \\
\text { meinkuch } \\
\text { meethahoj } \\
\text { aaye } \\
\end{array}$ & $\begin{array}{l}\text { Here the whole family is sitting and dining and since } \\
\text { it is the habit to eat sweet with dinner everyone and } \\
\text { even the kids understand that Mithai means Dairy } \\
\text { Milk }\end{array}$ \\
\hline 17 & 2011 & https://www.youtube.com/watch?v=d8lclD $5 \mathrm{cn} 0 \mathrm{~g}$ & $\begin{array}{l}\text { Cadbury } \\
\text { Dairy } \\
\text { Milk in } \\
\text { Home - } \\
\text { Lauki : } \\
\text { Meetheme } \\
\text { inkuchme } \\
\text { ethahojaay } \\
\text { e }\end{array}$ & $\begin{array}{l}\text { Innovative items based on Lauki is being made by } \\
\text { the mother but everyone in the family runs away } \\
\text { after hearing it. }\end{array}$ \\
\hline
\end{tabular}

Exhibit8:Cadbury's Ad Campaigns 